\title{
Effect of Acceleration on Wrap Faced Reinforced Soil Retaining Wall on Soft Clay by Performing Shaking Table Test
}

\author{
Ripon Hore ${ }^{1, *}$, Sudipta Chakraborty ${ }^{2}$, Ayaz Mahmud Shuvon $^{2}$, Mehedi Ahmed Ansary $^{1}$ \\ ${ }^{1}$ Department of Civil Engineering, Bangladesh University of Engineering and Technology, Dhaka, Bangladesh \\ ${ }^{2}$ Bangladesh Network Office for Urban Safety (BNUS), Bangladesh University of Engineering and Technology, Dhaka, Bangladesh \\ Received 21 June 2019; received in revised form 03 October 2019; accepted 03 January 2020
}

DOI: https://doi.org/10.46604/peti.2020.4485

\begin{abstract}
This research incorporates shaking table testing of scale wrap faced soil wall models to evaluate the seismic response of embankment. Currently the seismic designs of highway or railway embankment rely on little or no empirical data for calibrating numerical simulations. This research is working towards filling that empirical data gap. The specific purpose of the study was to evaluate the seismic response of constructed embankment model regarding the different input base accelerations with fixed frequency. A series of one-dimensional (1D) shaking table tests $(0.05 \mathrm{~g}, 0.1 \mathrm{~g}, 0.15 \mathrm{~g}$ and $0.2 \mathrm{~g})$, were performed on a 0.4 meters high wrap faced reinforced-soil wall model. Additionally, it was placed over 0.3 meters high soft clayey foundation. Predominantly, the influence of the base acceleration on the seismic response was studied in this paper. The physical models were subjected to harmonic sinusoidal input motions at a fixed frequency of $1 \mathrm{~Hz}$, in order to assess the seismic behavior. The effects of parameters such as acceleration amplitudes and surcharge pressures on the seismic response of the model walls were considered. The relative density of the backfill material was kept fixed at $60 \%$. The results of this study reveal that input accelerations and surcharge load had significant influence on the model wall, pore water pressure, and changes along the elevation. Acceleration response advances with the increase in base acceleration, so the difference being more perceptible at higher elevations. The pore water pressures were found to be high for high base shaking and low surcharge pressures at higher elevations. The results obtained from this study are helpful in understanding the relative performance of reinforced soil retaining wall under different test conditions resting on soft clay.
\end{abstract}

Keywords: reinforced embankment, soft clayey soil foundation, input acceleration, sinusoidal input motions, input frequency, surcharge load, pore water pressure, shaking table test

\section{Introduction}

Highways are essential lifelines that should be in operation even after disastrous events. For that reason, during and after earthquakes, earth structures such as highway embankments should be stable enough to provide required safety and emergency needs. The soil-foundation composed of clayey soil has become the focus of earthquake engineering in more cases. However, it is challenging to study the characteristic of pore water pressure in such a clayey soil-foundations under an earthquake action. Although such a soil-foundations of higher clay content, a rise of excess pore water pressure triggered by earthquakes and a drop of effective stress may lead to the soil softening. Moreover, soil-foundation softening may cause damage to the embankment. Thus, engineering judgment and application are required to reinforce the embankment to acquire the stability conditions. Geosynthetics have proven to be useful and cost-effective site improvement materials. They have become essential materials in civil engineering and environmental geotechnics. Application of the geosynthetics in highway embankments provides an additional tensile strength and durability to the structures under horizontal and vertical loads, so it enables engineers to construct more stable and earthquake resistant highway embankments [1-2]. The researches in geotechnical

* Corresponding author. E-mail address: riponhore@gmail.com

Tel.: +88-02-8181162; Fax: +88-02-9136751 
engineering fields witnessed distinguishable developments in the methods and techniques of studying the engineering problems concerning dynamic effects and seismic performance of structural elements problems. Physical modeling is on one of these techniques, which principles were widely used on different small-scale models shaking table test demonstrating different prototypes scale around the worlds [3]. Different sizes of shaking table were designed and used throughout the world to solve problems under different dynamic motions and analyze its effect [4]. Design, development, calibration and performance of this equipment are very important [5]. Humaish et al. [6] and Chau et al. [7] were investigated different geotechnical and engineering problems which deals with designing, manufacturing, and testing of small shaking table.

Worldwide many researchers [8-9] conducted shaking table tests on geosynthetics reinforced soil wall in different times. Srilatha et al. [10] and Edinçliler and Toksoy [11] were performed to reduce scale shaking table test on model embankment to compare the behavior of reinforced and unreinforced embankment under both earthquake with uniform cyclic loading. Yazdandoust [12] conducted a series of one gravitational shaking table tests under harmonic as well as seismic loading on 0.9 meters high reinforced-soil wall models to assess the behavior of the models. Zhou et al. [13] presented shaking table tests on three aeolian sand high embankment models. Moreover, shaking is an effective technique to study the seismic response of underground structures embedded in soft soil sites. Goktepeet al. [14] observed that the local soil properties have considerably amplified the earthquake response of the structures in comparison to the fixed base structure. Çelebi et al. [15] specified a realistic geometric scaling coefficient for test model to be used in a small-capacity shaking table. The scaling factor addressed in this study involves not only geometric similarity but also kinematic and dynamic similarity with the real system. The dynamic parameters for scaled model of a single layer soil are restricted with base-rock which has been compared numerically with the proposed laminar soil container to provide a good agreement [16]. Many researchers [17-19] performed shaking table test, to study the seismic responses of underground structures embedded in soft soil. Moreover, it is necessary to consider the influence of pore pressure in soft soil sites.

It is understood from the above literature that, the reinforced soil retaining wall on soft clay is prevalent in all over the world. Moreover, it is very important to consider seismic loading in design phase. Keep everything in concern, a 1/10 scaled geosynthetics wrap faced embankment model was designed for this study in order to investigate the effect of different input motions with differences in amplitude and fixed frequency. Twelve shaking table test were carried out on this model embankment. During the experiments, accelerations moving through the embankment as well as the vertical and horizontal displacement values for each motion were obtained. The total method of this study is presented thorough a flowchart in Figure 1. The effect of acceleration on the model wall was studied. Moreover, the effect of acceleration on surcharge and pore water pressure were also investigated.

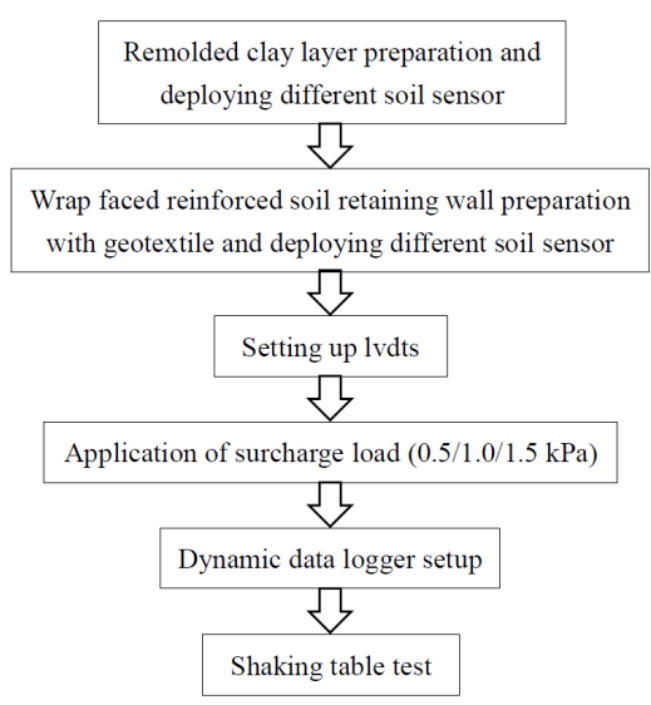

Fig. 1 Flow chart of research methodology 
The objectives of this study were to (a) conduct a series of shaking tests effectively under different base acceleration with fixed frequency, (b) fix a suitable scaling for constructing a dummy embankment, (c) observe the behavior of wrap-faced reinforced soil wall, (d) observe the seismic response of the scaled model embankment due to acceleration of base shaking and (e) determine the layer by layer response of soil wall due to these shakings. The specific purpose of the study was to evaluate the seismic response of constructed embankment model regarding the different input base accelerations with fixed frequency.

\section{Testing Equipment's}

\subsection{Shaking table}

A single degree shaking table was used to simulate the horizontal shaking action, associated with seismic and other vibration conditions. The testing platform was made of steel ( $2 \mathrm{~m}$ by $2 \mathrm{~m}$ ), had $1350 \mathrm{~kg}$ of payload capacity as shown in Fig. 2 . Shaking was provided by a digitally controlled servo-hydraulic actuator. It had an acceleration range from $0.01 \mathrm{~g}$ to $4 \mathrm{~g}$ and frequency range from $0.05 \mathrm{~Hz}$ to $50 \mathrm{~Hz}$ with maximum amplitude of $\pm 200 \mathrm{~mm}$.

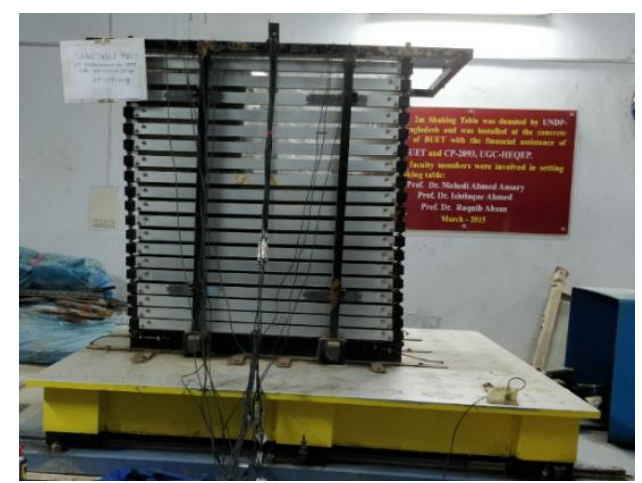

Fig. 2 Laminar box mounted on the shaking table

\subsection{Used container}

The ideal container was one that gave a seismic response of the soil model identical to that obtained in the prototype. In this study, embankment with soft clayey soil models was constructed in a laminar box to reduce boundary effects as far as practicable. The laminar shear box developed at the laboratory was composed of 24 hollow aluminum layers of frames is presented in Fig. 1. Each layer consisted of an inner frame with inside dimensions of $915 \mathrm{~mm} \times 1220 \mathrm{~mm} \times 1220 \mathrm{~mm}$. The gap between the successive layers was $2 \mathrm{~mm}$, and the most bottom layer was rigidly connected to the solid aluminum base plate of size $915 \mathrm{~mm}$ x $1220 \mathrm{~mm}$ in plan and $15 \mathrm{~mm}$ thickness.

\subsection{Air pluviation technique}

In order to achieve the same density characteristics for the sandy soil specimen, three common techniques are obtainedvibration, taming and pluviation. In this study, a portable traveling pluviator was used for achieving desired relative density, which was developed by Hossain and Ansary [20]. Desired relative density could be achieved by changing the height of fall.

\section{Testing Materials}

\subsection{Clayey soil}

The clayey soil sample was collected at a depth of $1.5 \mathrm{~m}$ below the existing ground level from nearby Campus of Bangladesh University of Engineering and Technology, Dhaka city of Bangladesh. The liquid and plastic limits are used internationally for soil identification, classification and strength correlations. The liquid limit was determined by performing trials in which a portion of the sample is spread in a brass cup, divided in two by a grooving tool, and then allowed to flow 
together from the shocks caused by repeatedly dropping the cup in a standard mechanical device. The plastic limit was determined by alternately pressing together and rolling into a $3.2-\mathrm{mm}(1 / 8 \mathrm{in})$ diameter thread a small portion of plastic soil until its water content was reduced to a point at which the thread crumbles and can no longer be pressed together and rerolled. Test procedures for obtaining the liquid and plastic limits are detailed in ASTM D 4318- Standard Test Methods for Liquid Limit, Plastic Limit and Plasticity Index of Soils. Three samples were prepared for measuring liquid limit (LL) and plastic limit (PL). Three liquid limit (LL) and plastic limit (PL) were 36.5\%, 37.0\%, 39.5\% and 13.5\%, 14.0\%, 16.5\%, respectively. Average liquid limit (LL) and plastic limit (PL) were established to be $38 \%$ and $15 \%$, respectively. Moreover, the average plasticity index was 23. The soil was defined as Lean Clay (CL), as per as USCS classification. The geotechnical property of the clayey soil is summarized in Table 1.

Table 1 Properties of clayey soils

\begin{tabular}{cccccccccc}
\hline Soil & $\begin{array}{c}\gamma^{*}{ }_{\text {unsat }} \\
\left(\mathrm{kN} / \mathrm{m}^{3}\right)\end{array}$ & $\begin{array}{c}\gamma_{\text {sat }} \\
\left(\mathrm{kN} / \mathrm{m}^{3}\right)\end{array}$ & $\begin{array}{c}\mathrm{C} \\
(\mathrm{kPa})\end{array}$ & $\begin{array}{c}\emptyset \\
\left({ }^{\circ}\right)\end{array}$ & Specific gravity $\left(\mathrm{G}_{\mathrm{s}}\right)$ & $\mathrm{LL}$ & $\mathrm{PL}$ & $\begin{array}{c}\text { Permeability } \\
\text { coefficient } \\
\left(\mathrm{ms}^{-1}\right)\end{array}$ & Soil Porosity \\
\hline Clayey & 15 & 18 & 26 & 20 & 2.62 & $38 \%$ & $15 \%$ & $3 \times 10^{-7}$ & 0.6 \\
\hline
\end{tabular}

\subsection{Remolded clayey soil}

In this study, clayey soil was reconstituted by thoroughly mixing the oven-dried clayey soil powder with an initial water content equal to the LL [21]. The thorough mixing of the slurry was attained with the aid of a 'Hobart' rotary mixer. With this slurry, a $300 \mathrm{~mm}$ reconstituted clayey soil layer was at first constructed in the laminar shear box; and then consolidated under the drained isotropic condition at loads: $15 \mathrm{kPa}, 20 \mathrm{kPa}, 25 \mathrm{kPa}, 30 \mathrm{kPa}, 40 \mathrm{kPa}, 60 \mathrm{kPa}, 80 \mathrm{kPa}$ and, $100 \mathrm{kPa}$, respectively. The consolidation process was observed through the settlement of clayey soil versus time graph, plotted with the aid of calibrated mechanical dial gauges, instrumented on either side of the laminar shear box. The average settlement curve is shown in Fig. 3. The value of effective stress ( $\left.\mathrm{c}^{\prime}\right)$ was $26 \mathrm{kPa}$ obtained from the Unconsolidated Undrained (UU) Triaxial Compression test.

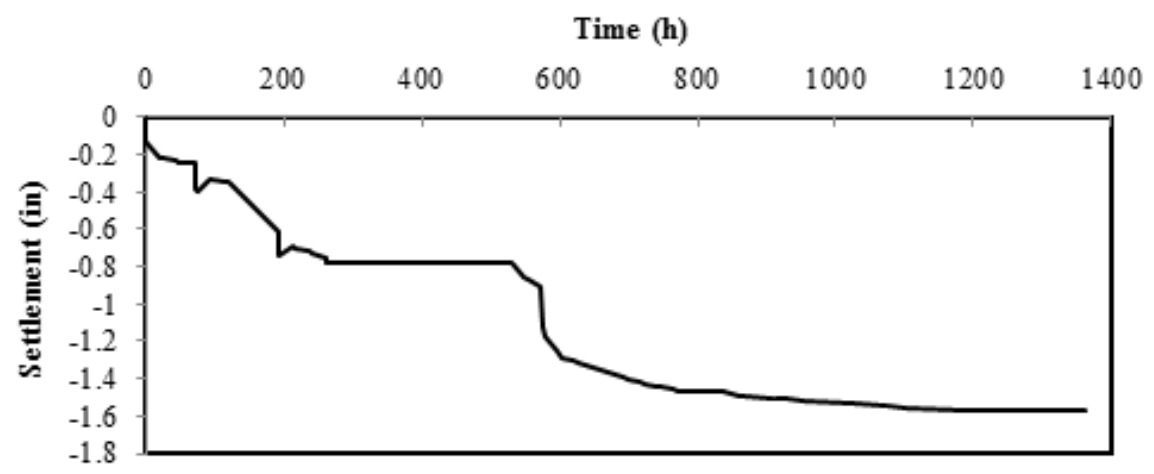

Fig. 3 Settlement curve

\subsection{Sandy soil}

The sand material used during the experiments is named as "Sylhet Sand" which is locally found and it is widely used for highway embankments. The coefficient of uniformity $\left(\mathrm{C}_{\mathrm{u}}\right)$ and the coefficient of curvature $\left(\mathrm{C}_{\mathrm{c}}\right)$ were estimated as 2.16 and 0.66 , respectively from this curve and the results indicating a poorly graded, medium to fine sand (SP). Moreover, fineness modulus was determined to be at 2.66. Other physical parameters such as specific gravity $\left(\mathrm{G}_{\mathrm{s}}\right)$ and maximum dry density $\left(\gamma_{\mathrm{d}}\right)$ were determined to be 2.64 and $16.8 \mathrm{kN} / \mathrm{m}^{3}$, respectively. Strength parameters were determined by using the direct shear test. The test establishes an internal angle of friction $\phi$ of $32^{\circ}$. The properties of the target sandy soil is presented Table 2 .

Table 2 Properties of the sandy soils

\begin{tabular}{cccccccccc}
\hline Soil & $\begin{array}{c}\gamma^{*} \text { unsat } \\
\left(\mathrm{kN} / \mathrm{m}^{3}\right)\end{array}$ & $\begin{array}{c}\gamma_{\mathrm{sat}} \\
\left(\mathrm{kN} / \mathrm{m}^{3}\right)\end{array}$ & $\mathrm{e}_{\max }$ & $\mathrm{e}_{\min }$ & $\mathrm{C}_{\mathrm{u}}$ & $\mathrm{C}_{\mathrm{c}}$ & $\begin{array}{c}\mathrm{C} \\
(\mathrm{kPa})\end{array}$ & $\begin{array}{c}\varnothing \\
\left({ }^{\circ}\right)\end{array}$ & $\begin{array}{c}\text { Specific } \\
\text { gravity }\left(\mathrm{G}_{\mathrm{s}}\right)\end{array}$ \\
\hline Sandy & 16.8 & 20 & 0.875 & 0.550 & 2.16 & 0.66 & 0 & 32 & 2.64 \\
\hline
\end{tabular}




\subsection{Reinforcing material}

A non-woven polypropylene multifilament geotextile (DF50) was used for reinforcing the sand in the tests. The ultimate tensile strength of the geotextile was $15.5 \mathrm{kN} / \mathrm{m}$. Moreover, the ultimate tensile strength at $5 \%$ strain of the geotextile was $16.57 \mathrm{kN} / \mathrm{m}$. Tensile properties of geotextile were determined by using the universal tensile testing machine. Tensile test (ASTM D 4595) 1500 scale was used for wide width strip [22]. Elongation of specimens with respect to gradually increased load was measured manually. The average initial modulus $\left(\mathrm{E}_{\mathrm{i}}\right)$ and secant modulus $\left(\mathrm{E}_{\mathrm{s}}\right)$ in both directions $(\mathrm{X}$ and $\mathrm{Y})$ were 0.039 $\mathrm{kPa}, 0.1407 \mathrm{kPa}$, and $0.0467 \mathrm{kPa}, 0.1230 \mathrm{kPa}$, respectively. Several researchers [23-25] have investigated the degree of improvement achieved with different reinforcement lengths. As seen from the studies in the literature, there is no unique value proposed for the reinforcement length. Furthermore, the reinforcement must have sufficient length and stiffness [26]. In this study the geotextile reinforcement length was $700 \mathrm{~mm}$, to wrap each sand layer properly.

\section{Model Design Considerations}

The embankment model was properly scaled to achieve similitude with the prototype since it is not possible to predict the accurate behavior of the prototype with comparison to reinforced model wall in $1 \mathrm{~g}$ gravitational field [27-28]. The scaling factors for this study was exponent of confining pressure $(\alpha)=0.5$ for sand [22] considering the prototype to model scale being $\lambda=10$ as presented in Table 3 . Keeping in mind, the container size and the capacity of the shaking table, the value of $\lambda$ was considered. The reliability of model tests depends on whether the model can represent the real behavior of the prototype system. Model size in this study was fixed according to the facilities available for this test. Precise scaling of soil walls and reinforcement properties is needed for considering the stress-dependent behavior of the soil and boundary conditions.

Table 3 Scale relations and ratio of model system

\begin{tabular}{ccccc}
\hline Description & Parameter & Scale factor & Scale factor M/P & Scale factor P/M \\
\hline Acceleration & $\mathrm{a}$ & 1 & 1 & 1 \\
Density & $\rho$ & 1 & 1 & 1 \\
Length & $\mathrm{L}$ & $1 / \lambda$ & 0.10 & 10 \\
Stress & $\sigma$ & $1 / \lambda$ & 0.10 & 10 \\
Strain & $\mathrm{g}$ & $1 / \lambda^{1-\alpha}$ & 0.32 & 3.125 \\
Displacement & $\mathrm{d}$ & $1 / \lambda^{2-\alpha}$ & 0.031 & 32.25 \\
Frequency & $\mathrm{f}$ & $\lambda^{1-\alpha / 2}$ & 5.62 & 0.18 \\
Time & $\mathrm{t}$ & $1 / \lambda^{1-\alpha / 2}$ & 0.178 & 5.62 \\
\hline
\end{tabular}

*P-Prototype; M-Model

\subsection{Soft soil foundations}

In the southern and central part (Dhaka city) of Bangladesh, the clay layer thickness is comparatively higher than others part of the country [29]. This clay layer thickness affects the foundation design. According to this, Dhaka soft clayey soil was considered as the target prototype of the foundation soil. The present study was conducted with a thickness of $300 \mathrm{~mm}$ (12 inch) clayey soil layer foundation above which a $50 \mathrm{~mm}$ and the sand blanket was provided as shown in Fig. 4. Approximately $1 \mathrm{~m} 2$ geotextile was placed between the clayey soil foundation and sand blanket. Considering the prototype to model scale being $\lambda$ $=10$ and scale factor $1 / \lambda$, the height of the prototype was 3 meters.

\subsection{Model embankment}

Wall height is a significant factor of governing scale effects and the reaction of the model in contrast with the prototype. The higher height of sand wall provided better result. The average height of traditional walls usually ranges from 4.0 to $5 \mathrm{~m}$ [23]. Many shaking table tests, on the different height of the sand wall such as $0.5 \mathrm{~m}$ [30], $0.6 \mathrm{~m} \mathrm{[22],1} \mathrm{m}$ [31], and 2.8 $\mathrm{m}$ [32] were performed at various time. A $400 \mathrm{~mm}$ high model with scale factor of 10 was constructed for this current study. The schematic geometry of the experimental model for this study is shown in Fig. 5. The sand wall consisted of 4 (four) layers and 
each layer was $100 \mathrm{~mm}$. Wrap-around type wall facing was used with flexible geotextile in the present study as shown in Fig. 4. Each individual facing was shaped by wrapping each layer with soft flexible geotextile element. However, in each individual test $60 \%$ relative density was kept by maintaining $150 \mathrm{~mm}$ height of fall. Concrete slab was used as surcharge load at the top of the upper layer of the model wall is presented in Fig. 4. Three different types of $0.5 \mathrm{kPa}, 1.0 \mathrm{kPa}$ and $1.5 \mathrm{kPa}$ surcharge loads were employed in this study.

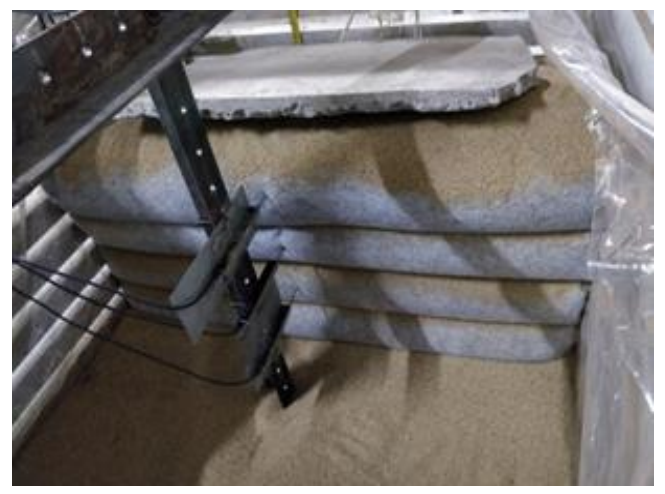

Fig. 4 Wrap-faced wall with LVDT

\section{Shaking Table Test}

\subsection{Instrumentation}

Fifteen sensors were used for this shaking table study; there are six accelerometers and four strain gauges, two pore pressure sensors and three displacement sensors. Accelerometers, strain gauges, pore pressure and displacement sensors are notated with A, Sg, P and LVDT, respectively. A1 was positioned on the shaking table to measure the input base motion. A2 was located on the clayey soil layer; A3, A4, A5 and A6 were placed inside the sand wall and located linearly at the different level. Both the pore pressure sensors (P1 and P2) were placed on clayey soil layer. The four strain gauges were placed inside the embankment and attachment with geotextile. Three displacement transducers (LVDT1, LVDT2, and LVDT3) were placed at different elevations from the sand blanket along the wall facing to measure horizontal displacement. A schematic view of the studied model with instrumentation plan is depicted in Fig. 5.

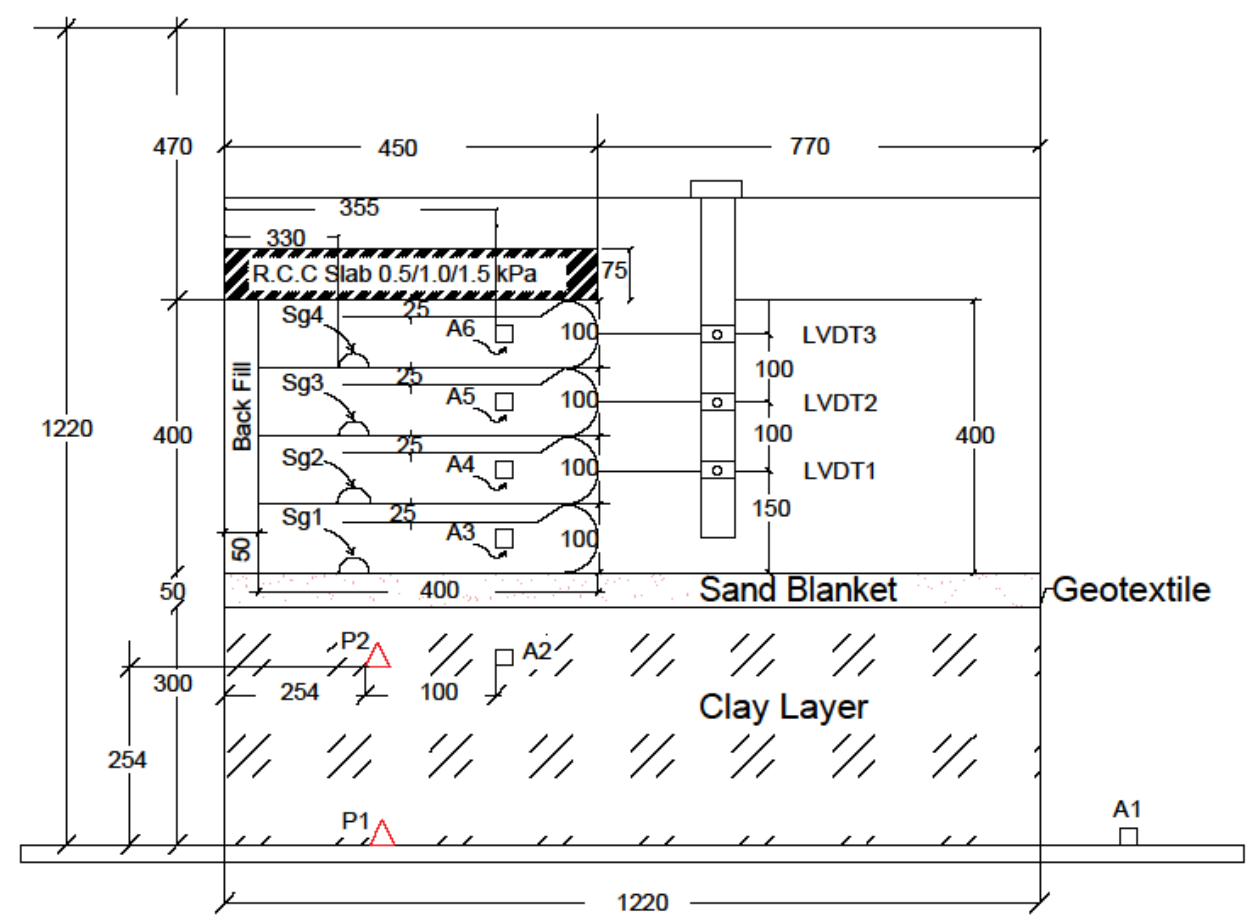

Fig. 5 Experimental setup design (All dimensions are in $\mathrm{mm}$ ) 


\subsection{Input motions}

This current study covers determination of the effects of acceleration amplitude, predominant surcharge and frequency of the motion on the seismic performance of reinforced embankment models. Only $1 \mathrm{~Hz}$ frequency was used in the present study which is less than the natural frequency $(68 \mathrm{~Hz})$ of the embankment model. In order to do so, the applied dynamic motions cannot create any resonance. Input dynamic motions consist of sinusoidal base motions of four acceleration amplitudes $(0.05 \mathrm{~g}$, $0.10 \mathrm{~g}, 0.15 \mathrm{~g}$ and $0.20 \mathrm{~g})$ with three predominant surcharges $(0.5 \mathrm{kPa}, 1.0 \mathrm{kPa}$ and $1.5 \mathrm{kPa})$ and $1 \mathrm{~Hz}$ frequency. Different researchers [23] mentioned that this harmonic sinusoidal base acceleration is more aggressive than an archetypal earthquake with the same predominant frequency and amplitude. Total 12 numbers of harmonic sinusoidal shaking were performed with using the designed laminar shear box for this research is presented in Table 4.

Table 4 Loading schemes of the shaking table tests

\begin{tabular}{ccccc}
\hline Test Name & Acceleration, $g$ & Frequency, Hz & Surcharge Load, kPa & Relative Density, $\%$ \\
\hline RT1 & 0.05 & 1 & & \\
RT2 & 0.1 & 1 & 0.5 & \\
RT3 & 0.15 & 1 & & \\
RT4 & 0.2 & 1 & & \\
RT5 & 0.05 & 1 & 1.0 & \\
RT6 & 0.1 & 1 & & \\
RT7 & 0.15 & 1 & & \\
RT8 & 0.2 & 1 & & \\
RT9 & 0.05 & 1 & 1.5 & \\
RT10 & 0.1 & 1 & & \\
RT11 & 0.15 & 1 & & \\
RT12 & 0.2 & 1 & & \\
\hline
\end{tabular}

\section{Results and Discussions}

Results were obtained from several shaking table tests on the embankment with soft clayey soil model is discussed in this section. Reinforced-soil wall was constructed by using sand upon the clayey soil layer in equal lifts (EL) of $100 \mathrm{~mm}$ (4 inch) to achieve a total wall height $(\mathrm{H})$ of $400 \mathrm{~mm}$. The length $(\mathrm{L})$ of the geotextile reinforcement at the interface of the sand layers was kept the same in all tests as $510 \mathrm{~mm}$ (20 inch). After accomplishing the full setup, each wall model was subjected to 30 cycle's sinusoidal motions of shaking at predetermined frequency, acceleration, amplitude and surcharge load as mentioned in Table 3.

\subsection{Acceleration amplification response}

Figs. (6)-(8) compared the acceleration amplification profile with the height of the wall for different surcharge $(0.5,1.0$ and $1.5 \mathrm{kPa})$, base motion $(0.05 \mathrm{~g}, 0.1 \mathrm{~g}, 0.15 \mathrm{~g}$ and $0.2 \mathrm{~g})$ with fixed frequency $(1 \mathrm{~Hz})$ and $60 \%$ relative density after each test. Here, the elevation (s) was represented in non-dimensional form after normalizing by the full wall height (H). Fig. 6 showed the acceleration amplifications along the height of the wall for different base accelerations of 0.05, 0.1, 0.15 and 0.2 $\mathrm{g}$ from RT1 $(0.05 \mathrm{~g}, 1 \mathrm{~Hz}$ and $0.5 \mathrm{kPa}), \mathrm{RT} 2(0.1 \mathrm{~g}, 1 \mathrm{~Hz}$ and $0.5 \mathrm{kPa}), \mathrm{RT} 3(0.15 \mathrm{~g}, 1 \mathrm{~Hz}$ and $0.5 \mathrm{kPa})$ and RT4 $(0.2 \mathrm{~g}, 1 \mathrm{~Hz}$ and $0.5 \mathrm{kPa}) \mathrm{model}$ tests, respectively, which were conducted at $1 \mathrm{~Hz}$ frequency, $0.5 \mathrm{kPa}$ surcharge. Maximum acceleration amplification was observed at the top of the wall in all the tests. Fig. 7 showed the acceleration amplifications along the height of the wall for different base accelerations of 0.05, 0.1, 0.15 and $0.2 \mathrm{~g}$ from RT1 $(0.05 \mathrm{~g}, 1 \mathrm{~Hz}$ and $1.0 \mathrm{kPa}), \mathrm{RT} 2(0.1 \mathrm{~g}, 1 \mathrm{~Hz}$ and $1.0 \mathrm{kPa}), \mathrm{RT} 3$ $(0.15 \mathrm{~g}, 1 \mathrm{~Hz}$ and $1.0 \mathrm{kPa})$ and RT4 $(0.2 \mathrm{~g}, 1 \mathrm{~Hz}$ and $1.0 \mathrm{kPa})$ model tests, respectively, which were conducted at $1 \mathrm{~Hz}$ frequency, $1.0 \mathrm{kPa}$ surcharge. Besides, Fig. 8 showed the acceleration amplifications along the height of the wall for different base accelerations of $0.05,0.1,0.15$ and $0.2 \mathrm{~g}$ from RT1 $(0.05 \mathrm{~g}, 1 \mathrm{~Hz}$ and $1.5 \mathrm{kPa}), \mathrm{RT} 2(0.1 \mathrm{~g}, 1 \mathrm{~Hz}$ and $1.5 \mathrm{kPa}), \mathrm{RT} 3(0.15 \mathrm{~g}, 1 \mathrm{~Hz}$ and $1.5 \mathrm{kPa})$ and RT4 $(0.2 \mathrm{~g}, 1 \mathrm{~Hz}$ and $1.5 \mathrm{kPa})$ model tests, respectively, which were conducted at $1 \mathrm{~Hz}$ frequency, $1.5 \mathrm{kPa}$ surcharge. From the figures, it is clear that maximum acceleration amplification was observed at the top of the wall in the tests. Moreover, acceleration amplifications were increased with increase of base acceleration in soil layer. Within the range of tests 
conducted, acceleration amplifications at the top of the wall for $0.2 \mathrm{~g}$ base accelerations were $1.52,1.41$ and 1.29 for the surcharge $0.5,1.0$ and $1.5 \mathrm{kPa}$, respectively. This observation is in concurrence with the results of physical tests reported by Krishna et al. [22].

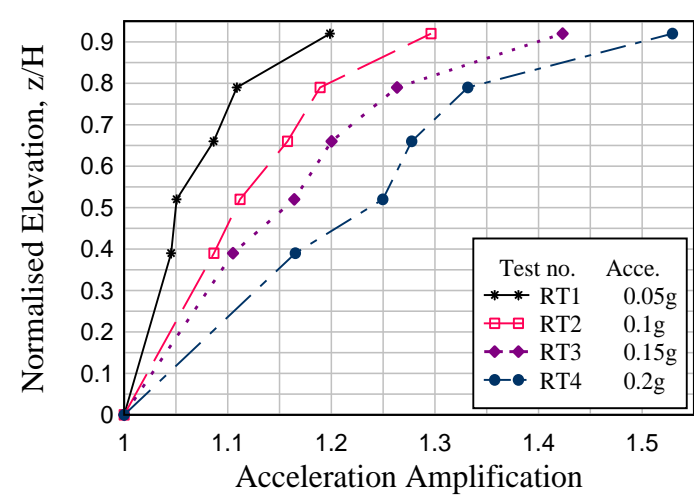

Fig. 6 Effect of base acceleration on acceleration amplification (Surcharge $0.5 \mathrm{kPa}$ )

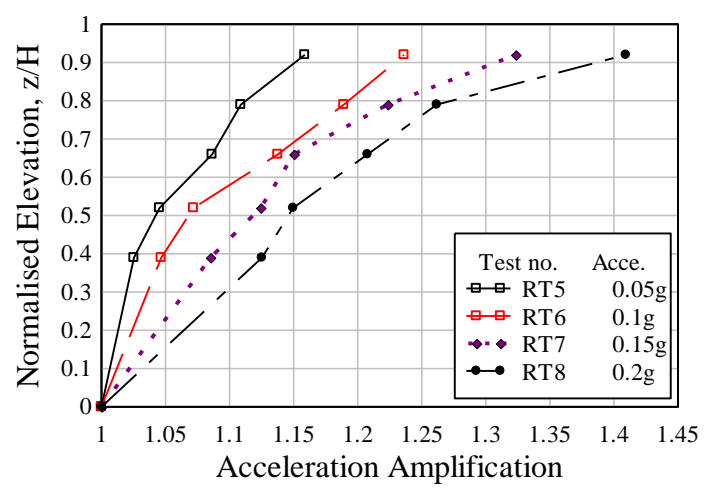

Fig. 7 Effect of base acceleration on acceleration amplification (Surcharge $1.0 \mathrm{kPa}$ )

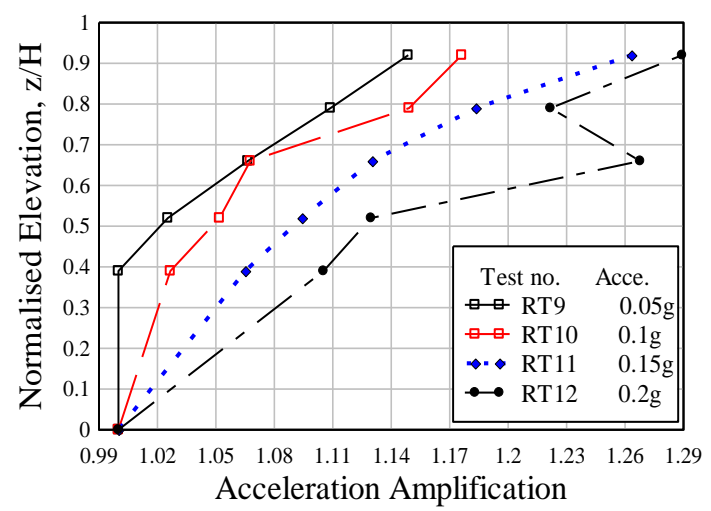

Fig. 8 Effect of base acceleration on acceleration amplification (Surcharge $1.5 \mathrm{kPa}$ )

\subsection{Effect of acceleration on face displacement}

Horizontal face displacement along the height of the wall was monitored by using three LVDTs positioned is shown in Figs. 4, (9)-(11) present the displaced face profiles from numerous shaking table test analysis. Here elevation (s) and horizontal displacements $(\Delta \mathrm{h})$ are presented in non-dimensional from after normalizing them by the height of the wall $(\mathrm{H})$.

The normalized displacement profile for different base accelerations of $0.05 \mathrm{~g}, 0.1 \mathrm{~g}, 0.15 \mathrm{~g}$ and $0.2 \mathrm{~g}$ from tests RT1, RT2, RT3 and RT4 respectively, which were conducted at $1 \mathrm{~Hz}$ frequency and $0.5 \mathrm{kPa}$ surcharge pressure, is shown in Fig. 9. And, the normalized displacement profile for different base accelerations of $0.05 \mathrm{~g}, 0.1 \mathrm{~g}, 0.15 \mathrm{~g}$ and $0.2 \mathrm{~g}$ from tests RT5, RT6, RT7 and RT8 respectively, which were conducted at $1 \mathrm{~Hz}$ frequency and $1.0 \mathrm{kPa}$ surcharge pressure, is shown in Fig. 10. Also, the normalized displacement profile for different base accelerations of 0.05g, 0.1g, 0.15g and 0.2g from tests RT9, RT10, RT11 and RT12 respectively, which were conducted at $1 \mathrm{~Hz}$ frequency and $1.5 \mathrm{kPa}$ surcharge pressure, is shown in Fig. 11 . The figures depict that the normalized displacements were relatively high at higher base accelerations at the normalized elevation of $\mathrm{s} / \mathrm{H}=0.85$. A maximum horizontal displacement of $2.50 \%$ of the total wall height $(\mathrm{H})$, for $0.5 \mathrm{kPa}$ surcharge, was observed compared with $2.2 \%$ for $1.0 \mathrm{kPa}$ surcharge and $1.5 \%$ for $1.5 \mathrm{kPa}$. However, this observation is also in concurrence with the results of physical tests conducted by Krishna et al. [22].

\subsection{Effect of acceleration on pore water pressure}

Typical pore water pressure variations obtained from the tests are presented in Figs. (12)-(14). The height of clayey soil layer $(\mathrm{H})$ was taken as $300 \mathrm{~mm}$ in the case of pore water pressure. The variations of the pore water pressure from model tests 
RT1, RT2, RT3 and RT4 with base accelerations $0.01 \mathrm{~g}, 0.1 \mathrm{~g}, 0.15 \mathrm{~g}$ and $0.2 \mathrm{~g}$ respectively for $1 \mathrm{~Hz}$ frequency and surcharge load of $0.50 \mathrm{kPa}$ are shown in Fig. 12. And, the variations of the pore water pressure from model tests RT5, RT6, RT7 and RT8 with base accelerations $0.01 \mathrm{~g}, 0.1 \mathrm{~g}, 0.15 \mathrm{~g}$ and $0.2 \mathrm{~g}$ respectively for $1 \mathrm{~Hz}$ frequency and surcharge load of $1.0 \mathrm{kPa}$ is shown in Fig. 13. Besides, the variations of the pore water pressure from model tests RT9, RT10, RT11 and RT12 with base accelerations $0.01 \mathrm{~g}, 0.1 \mathrm{~g}, 0.15 \mathrm{~g}$ and $0.2 \mathrm{~g}$ respectively for $1 \mathrm{~Hz}$ frequency and surcharge load of $1.5 \mathrm{kPa}$ is shown in Fig. 14 . The pore water pressure response against base acceleration variation was directly proportional at $\mathrm{s} / \mathrm{H}=0.85$ as can be observed from the figures. The figures depict that pore water pressure increases with the increasing of acceleration. The maximum pore water pressure was $0.30,0.29$ and $0.27 \mathrm{kPa}$ at base acceleration of $0.2 \mathrm{~g}$ for the surcharge load $0.50 \mathrm{kPa}, 1.0 \mathrm{kPa}$ and $1.5 \mathrm{kPa}$ respectively. Moreover, this finding is similar to the results of Zhang et al. [33].

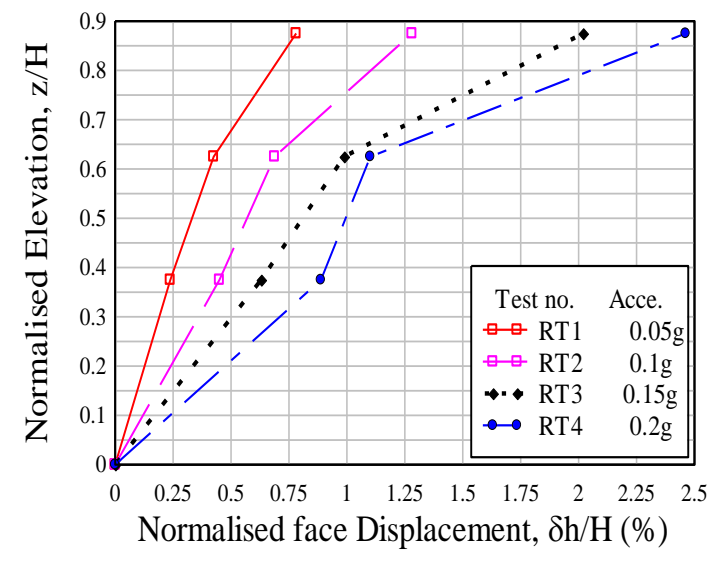

Fig. 9 Effect of base acceleration on face displacement (Surcharge $0.5 \mathrm{kPa}$ )

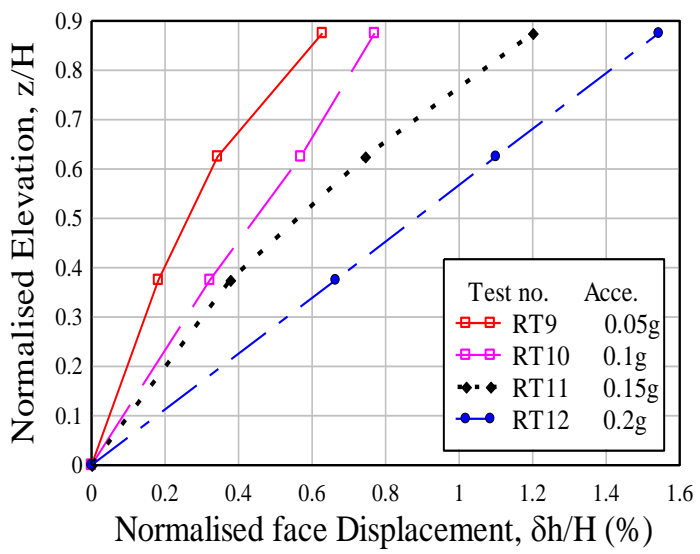

Fig. 11 Effect of base acceleration on face displacement (Surcharge $1.5 \mathrm{kPa}$ )

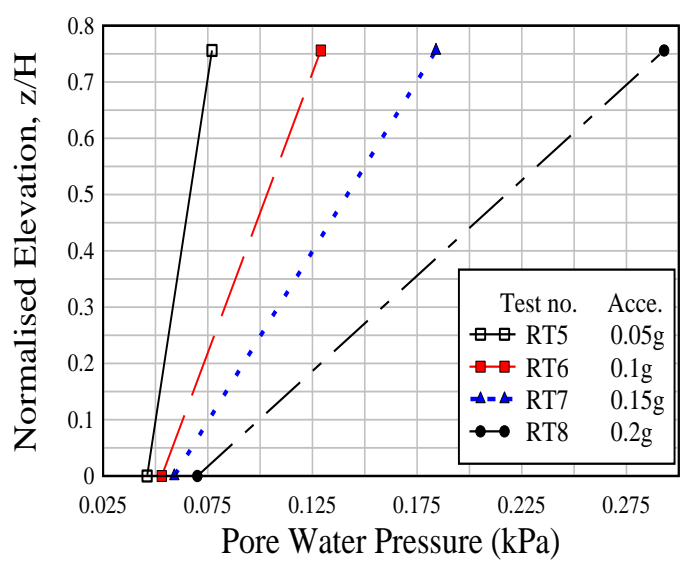

Fig. 13 Effect of base acceleration on pore water pressure (Surcharge $1.0 \mathrm{kPa}$ )

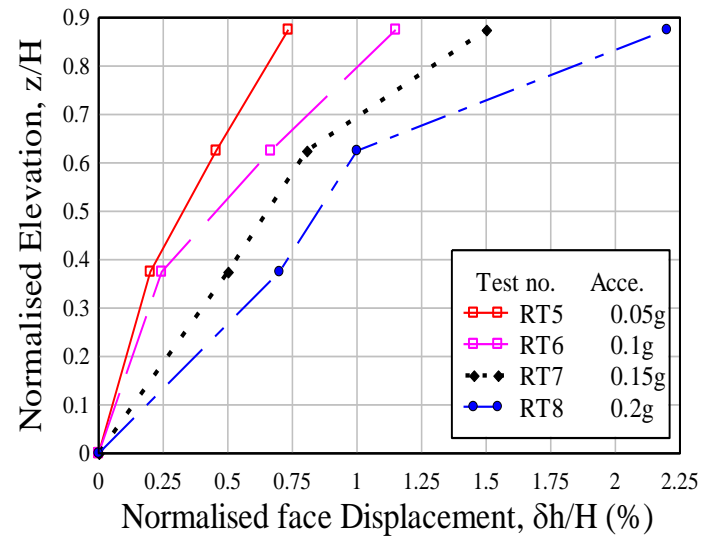

Fig. 10 Effect of base acceleration on face displacement (Surcharge $1.0 \mathrm{kPa}$ )

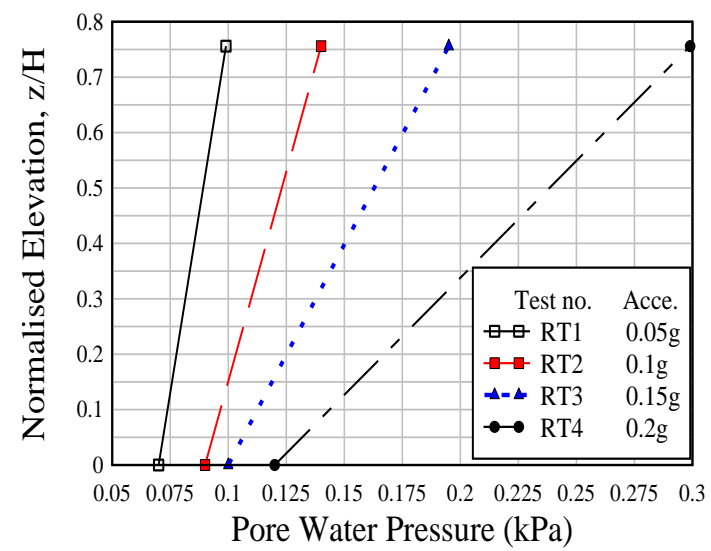

Fig. 12 Effect of base acceleration on pore water pressure (Surcharge $0.50 \mathrm{kPa}$ )

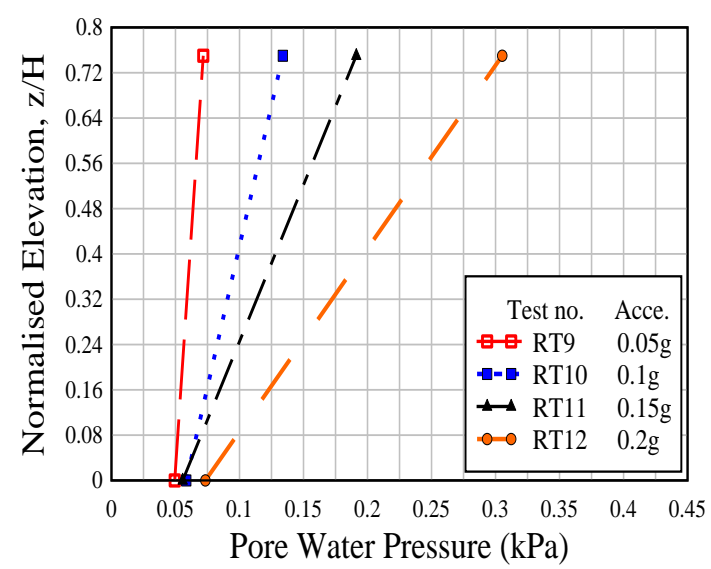

Fig. 14 Effect of base acceleration on pore water pressure (Surcharge $1.5 \mathrm{kPa}$ ) 


\section{Conclusions}

In this paper, foremost efforts were devoted to constructing a small-scale embankment (1/10 reduced scale) and experimenting of simple shaking table test to study the seismic response, especially the influence of input acceleration. Shaking table experiments were performed under twelve distinct dynamic motions under twelve single frequency motions (i.e. sine wave form) having four acceleration amplitudes, one fixed frequency and three predominant surcharge loads (0.50 $\mathrm{kPa}$, $1.0 \mathrm{kPa}$ and $1.50 \mathrm{kPa}$ ). Based on the tests in this study, the following conclusions can be drawn:

1. Acceleration response gets intensified with increase in base acceleration, the difference being more noticeable at higher elevations. However, as the base accelerations were increased, the acceleration amplifications were continued to increase. In all tests amplification of acceleration to maximum was observed at the top of the wall. Moreover, in clayey soil layer amplification of acceleration escalated with escalation of base acceleration. Acceleration amplifications at the top of the wall for $0.2 \mathrm{~g}$ base accelerations were $1.55,1.45$ and 1.37 for the surcharge $0.50 \mathrm{kPa}, 1.0 \mathrm{kPa}$ and $1.50 \mathrm{kPa}$, respectively. In general, accelerations were amplified both for sand and clayey soil layer, at higher elevations and with high base acceleration.

2. However, the face deformations were high for high base acceleration at the top of the reinforcing layer and impact was insignificant at the other layers. Normalized displacements were comparatively high at higher base accelerations at the normalized elevation of $\mathrm{s} / \mathrm{H}=0.85$. A maximum horizontal displacement of $2.20 \%$ of the total wall height $(\mathrm{H})$ for $0.50 \mathrm{kPa}$ surcharge was observed and compared with $2.0 \%$ total wall height $(\mathrm{H})$ for $1.0 \mathrm{kPa}$ surcharge and that of $1.7 \%$ for $1.50 \mathrm{kPa}$ surcharge. Generally, it can be said that accelerations were amplified (both in sand and clayey soil layer) at higher elevations and with low surcharge pressures. In general, the face deformations are high for low surcharge pressures.

3. The figures also illustrate that pore water pressure augmentation is proportional with the acceleration increment. The maximum pore water pressure was $0.30,0.29$ and $0.27 \mathrm{kPa}$ at base acceleration of $0.2 \mathrm{~g}$ for the surcharge load $0.50 \mathrm{kPa}, 1.0$ $\mathrm{kPa}$ and $1.50 \mathrm{kPa}$, respectively. However, the pore water pressures were high for high base shaking, and low surcharge pressures at higher elevations.

Although this study had limitations and performed with small scale, the results from this study provide useful directions in future regarding relative performance of reinforced soil wall on soft clay soil under various test conditions and provide guideline for further research.

\section{Conflicts of Interest}

The authors declare no conflict of interest.

\section{References}

[1] S. Denine, N. Della, M. R Dlawar, F. Sadok, J. Canou, and J. C. Dupla, "Effect of geotextile reinforcement on shear strength of sandy soil: laboratory study," Studia Geotechnica et Mechanica, vol. 38, no. 4, pp. 3-13, 2016.

[2] H. Aldeeky, O. Al Hattamleh, and B. A. Alfoul, "effect of sand placement method on the interface friction of sand and geotextile," International Journal of Civil Engineering, vol. 14, no. 2, pp. 133-138, March 2016.

[3] A. Joghataie and M. S. Dizaji, "Transforming results from model to prototype of concrete gravity dams using neural networks," Journal of Engineering Mechanics, vol. 137, no. 7, pp. 484-496, February 2012.

[4] T. S. Ueng, M. H. Wang, M. H. Chen, C. H. Chen, and L. H. Peng, "A large biaxial shear box for shaking table test on saturated sand," Geotechnical Testing Journal, vol. 29, no. 1, pp. 1-8, June 2005.

[5] A. Turan, S. D Hinchbergerand, and H. El Naggar, "Design and commissioning of a laminar soil container for use on small shaking tables," Soil Dynamics and Earthquake Engineering, vol. 29, no. 2, pp. 404-414, February 2009.

[6] A. H.Humaish, M. S. Shamkhi, and T. K. Al-Hachami, "Design, manufacturing and testing of small shaking table," International Journal of Engineering \& Technology, vol. 7, no. 4.20, pp. 426-430, 2018.

[7] K. T. Chau, C. Y. Shen, and X. Guo, "Nonlinear seismic soil-pile-structure interactions: shaking table tests and FEM analyses," Soil Dynamics and Earthquake Engineering, vol. 29, no. 2, pp. 300-310, February 2009. 
[8] M. Yazdandoust, "Study on seismic performance of reinforced soil walls to modify the pseudo static method," International Journal of Civil and Environmental Engineering, vol. 9, no. 9, pp. 1248-1259, 2015.

[9] H. I. Ling, Y. Mohri, D. Leshchinsky, B.Christopher, K.Matsushima, and H. Liu, "Large-scale shaking table tests on modular-block reinforced soil retaining walls," Journal of Geotechnical and Geoenvironmental Engineering, ASCE, vol. 131, no. 4, pp. 465-476, April 2005.

[10] N. Srilatha, G. M.Latha, and C. G. Puttappa, "Effect of frequency on seismic response of reinforced soil slopes in shaking table tests," Geotextiles and Geomembranes, vol. 36, pp. 27-32, February 2013.

[11] A. Edinçliler and Y. S. Toksoy, "Shake table tests to measure the dynamic performance of geotextile-reinforced embankment," PeriodicaPolytechnica Civil Engineering, vol. 61, no. 4, pp. 803-814, February 2017.

[12] M. Yazdandoust, "Investigation on the seismic performance of steel-strip reinforced-soil retaining walls using shaking table test," Soil Dynamics and Earthquake Engineering, vol. 97, pp. 216-232, June 2017.

[13] Z. Zhou, J. Lei, S. Shi, and T. Liu, "Seismic response of aeolian sand high embankment slopes in shaking table tests," Applied Sciences, vol. 9, no. 8, p. 1677, April 2019.

[14] F. Goktepe, E. Celebi, and A. J. Omid, "Numerical and experimental study on scaled soil-structure model for small shaking table tests," Soil Dynamics and Earthquake Engineering, vol. 119, pp. 308-319, April 2019.

[15] E. Çelebi, F. Göktepe, and A. J. Omid, "Seismic soil response of scaled geotechnical test model on small shaking table," Arabian Journal of Geosciences, vol. 12, no. 2, pp. 44, January 2019.

[16] F Goktepe, AJ Omid, and E Celebi, "Scaled soil-structure interaction model for shaking table testing," Acta Physica Polonica A, vol. 132, no. 3, pp.588-590, 2017.

[17] J. Chen, X. Shi and J. Li, "Shaking table test of utility tunnel under non-uniform earthquake wave excitation," Soil Dynamics and Earthquake Engineering, vol. 30, no. 11, pp. 1400-1416, November 2010.

[18] W. Cai, B. Yu, and S. Kaewunruen, "Shaking table tests of suspended structures equipped with viscous dampers," Applied Sciences, vol. 9, no. 13, pp. 1-16, June 2019.

[19] J. Ye and L. Jiang, "Simplified analytical model and shaking table test validation for seismic analysis of mid-rise cold-formed steel composite shear wall building," Sustainability, vol. 10, no. 9, pp. 1-18, September 2018.

[20] M. Z. Hossain and M. A. Ansary, "Development of a portable traveling pluviator device and its performance to prepare uniform sand specimens," Innovative Infrastructure Solutions, vol. 3, no. 1, p. 53, June 2018.

[21] N. Z. M. Yunus, D. Wanatowski, N. A. Hassan, and A. Marto, "Shear strength and compressibility behavior of lime-treated organic clay,” KSCE Journal of Civil Engineering, vol. 20, no. 5, pp. 1721-1727, July 2019.

[22] A. M. Krishna and G. M. Latha, "Seismic response of wrap-faced reinforced soil retaining wall models using shaking table tests," Geosynthetics International, vol. 14, no. 6, pp. 355-364, September 2007.

[23] M. El Sawwaf and A. K. Nazir, "Behavior of repeatedly loaded rectangular footings resting on reinforced sand," Alexandria Engineering Journal, vol. 49, no. 4, pp. 349-356, December 2010.

[24] E. Cicek, E. Guler, and T. Yetimoglu, "Effect of reinforcement length for different geosynthetic reinforcements on strip footing on sand soil," Soils and Foundations, vol. 55, no. 4, pp. 661-677, August 2015

[25] M. Zarringol, and M. Zarringol, "Study on the impact of sand-clay bond in geo-grid and geo-textile on bearing capacity," Journal of Sustainable Development, vol. 9, no. 6, pp. 83-95, November 2016.

[26] E. Cicek, E. Guler, and T. Yetimoglu, "Effects of the First reinforcement depth on different types of geosynthetics," Scientia Iranica, vol. 26, no. 1, pp. 167-177, 2019.

[27] M. Sabermahani, A. Ghalandarzadeh, and A. Fakher, "Experimental study on seismic deformation modes of reinforced-soil walls," Geotextiles and Geomembranes, vol. 27, no. 2, pp. 121-136, April 2009.

[28] G. M. Latha and A. M. Krishna, "Seismic response of reinforced soil retaining wall models: influence of backfill relative density," Geotextiles and Geomembranes, vol. 26, no. 4, pp. 335-349, August 2008.

[29] R. Hore, M. R. Arefin, and M. A. Ansary, "Development of zonation map based on soft clay for Bangladesh," Journal of Engineering, vol. 10, no. 1, pp. 13-18, March 2019.

[30] K. Watanabe, Y. Munaf, J. Koseki, M. Tateyama, and K. Kojima, "Behavior of several types of model retaining walls subjected to irregular excitation," Soils and Foundations, vol. 43, no. 5, pp. 13-27, 2003.

[31] M. M. El-Emam, and R. J. Bathurst, "Influence of reinforcement parameters on the seismic response of reduced-scale reinforced soil retaining walls," Geotextiles and Geomembranes, vol. 25, no. 1, pp. 33-49, February 2007.

[32] H. I. Ling, Y. Mohri, D. Leshchinsky, C. Burke, K. Matsushima, and H. Liu, "Large scale shaking table tests on modular-block reinforced soil retaining walls,” Journal of Geotechnical and Geo environmental Engineering, vol. 131, no. 4, pp. 465-476, April 2005.

[33] Z. Zhang, C. Cho, Q. Pan, and X. Lu, "Experimental investigation on excess pore water pressure in soft soil-foundations under minor shocks,” International Journal of Engineering and Applied Sciences, vol. 5, no. 4, pp. 259-263, 2009. 